\title{
The adaption of the South Africa sheep industry to new trends in animal breeding and genetics: A review
}

\author{
S.W.P. Cloete ${ }^{1,2 \#}$, J.J. Olivier ${ }^{2}$, L. Sandenbergh ${ }^{2,3}$ \& M.A. Snyman ${ }^{4}$ \\ ${ }^{1}$ Department of Animal Sciences, Private Bag X1, Matieland, 7602, South Africa \\ ${ }^{2}$ Directorate Animal Sciences: Elsenburg, Private Bag X1, Elsenburg, 7607, South Africa \\ ${ }^{3}$ Department of Genetics, Private Bag X1, Matieland, 7602, South Africa \\ ${ }^{4}$ Grootfontein ADI, Private Bag X529, Middelburg (EC) 5900, South Africa
}

(Received 20 March 2014; Accepted 12 July 2014; First published online 11 October 2014)

\author{
Copyright resides with the authors in terms of the Creative Commons Attribution 2.5 South African Licence. \\ See: http://creativecommons.org/licenses/by/2.5/za \\ Condition of use: The user may copy, distribute, transmit and adapt the work, but must recognise the authors and the South African \\ Journal of Animal Science.
}

\begin{abstract}
The history of sheep breeding research in South Africa can be divided roughly into four eras, namely the research and development phase, the commencement of recording and evaluation, the expansion of recording schemes, and, most recently, the adaptation of schemes to international benchmarks. The most recent era has presented scientists with the greatest challenges, namely the inclusion of genomic breeding values in routine sheep recording and of disease-resistance traits during routine evaluation. The establishment of reference populations for the major South African sheep breeds to estimate genomic breeding values is an immediate challenge. This process may be facilitated by a number of genetic resource flocks that are phenotyped for traits that are not routinely recorded in the national evaluation. A limited number of these animals are also genotyped. There is strong evidence that resistance of sheep to external and internal parasites is heritable, and may be improved by purposeful selection. Efforts should be concentrated on the inclusion of disease resistance traits in national analyses where appropriate. However, seen against the background that South African investment in research is appreciably less than in developed countries, lack of funding and high-capacity manpower may impede rapid progress. There thus seem to be many challenges for future generations of sheep breeding scientists.
\end{abstract}

Keywords: Capacity, disease resistance, genomic selection

\# Corresponding author: schalkc@elsenburg.com

\section{Background}

The environment: According to international standards, South Africa is an arid country. The bulk of the country can be described as ranging from hyper-arid to semi-arid (AGIS, 2007a). Almost the entire Northern Cape is classified as hyper-arid to arid, while substantial parts of the Western Cape, Eastern Cape, Limpopo and North West are regarded as arid. Semi-arid regions include the winter-rainfall cropping-pasture regions of the Western Cape, as well as the summer-rainfall cropping areas of Free State, North West and the Bushveld regions of Gauteng and Limpopo.

Apart from the relative aridity of the country, crop production is hampered by limitations in soil fertility and texture (AGIS, 2007b). According to the Abstract of Agricultural Statistics (2012), only 16.5\% of the approximately 86.2 million hectares of commercial agricultural land can be considered arable. Extensive small stock production is the dominant livestock industry in the drier western and northwestern parts of the country, with a grazing capacity well below 12 ha per large stock unit (Cloete \& Olivier, 2010). Numbers of extensive beef cattle increase in the eastern and northern directions, as average precipitation rises. Extensive small stock production is thus replaced largely by extensive beef production in the northern provinces. Meissner et al. (2013) provided detailed information about the distribution of livestock per province in South Africa, and thus this topic is not elaborated on.

The trend whereby sheep are replaced with beef cattle in northerly and easterly regions is evident in Figure 1, where the most important agricultural industries are depicted per district. Semi-extensive sheep farming is also important in the cropping-pasture regions, where ruminant livestock thrive on the by-products of capital- and labour-intensive cropping industries, while adding stability to the more risky cropping ventures. 


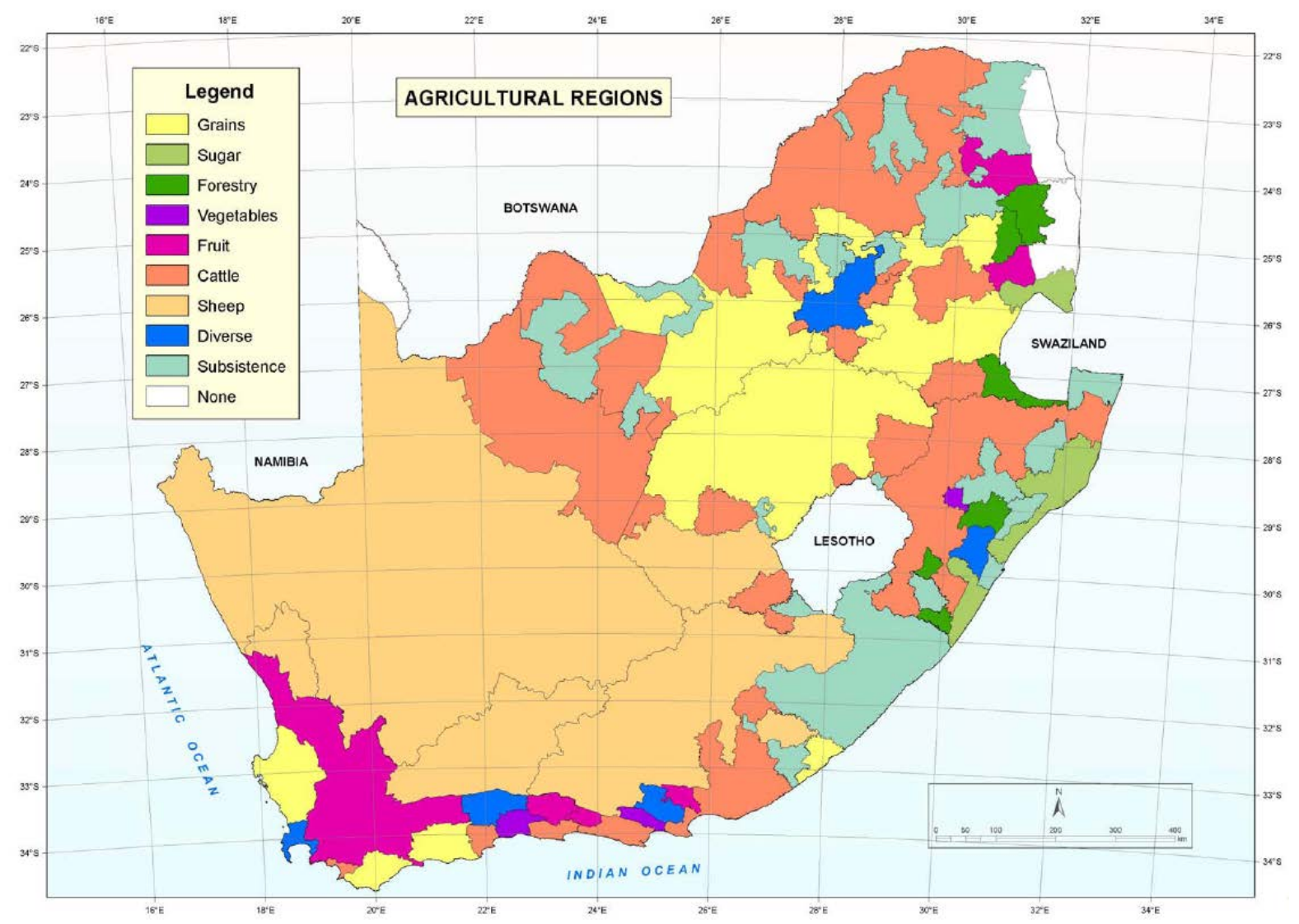

Figure 1 Most important agricultural industries in South Africa per district (source: AGIS, 2007c).

Livestock in South Africa: Income derived from animal products represents just below $50 \%$ of the gross domestic income of agricultural production in South Africa ( $R 67.7$ billion of a total gross domestic primary agricultural product of R 140.4 billion) (Abstract of Agricultural Statistics, 2012). At about $48 \%$ of the gross livestock production, poultry products are by far the dominant source of income for stock producers (Table 1), followed by beef and veal, fresh milk, sheep and goat meat, pork, and then small stock fibres. Although the contribution of sheep farming is modest in monetary terms, the industry is of major importance in the regional context and of strategic importance in the rural parts of the country (Cloete \& Olivier, 2010).

A recent review by Rust \& Rust (2013) suggested that small ruminants are relatively resilient to higher temperatures compared with other livestock. Small ruminants are also able to adapt to widely ranging climate conditions in terms of rainfall. Rust \& Rust (2013) suggested that increased temperatures because of climate change would bring about increasing numbers of sheep and goats. It is therefore fitting to review sheep breeding, the advances that have accrued in the past, and future prospects, which are needed to align the local industry with comparable industries abroad.

\section{Breeding sheep in South Africa}

In the past 50 years, sheep breeding in South Africa has gone through a number of phases. These phases can be summarized as follows:

Research and development phase: The sheep industry was supported by research conducted on specific genetic resource flocks under the auspices of several institutions. These were research flocks in planned experiments or flocks managed as studs according to the criteria for stud breeding at that stage. Schoeman et al. (2010) described these flocks in detail and no further information is provided in this document. However, the most important production traits, namely growth, reproduction and wool traits, were selected for in these flocks. It was demonstrated that all traits exhibited genetic variation that was transferable to future generations (Schoeman et al., 2010). Worthwhile genetic progress was therefore reported in research flocks for growth (Neser et al., 1995), number and weight of lamb weaned per mating (Cloete et al., 2004), clean fleece weight (Cloete et al., 1998) and fibre diameter (Cloete et al., 2013b). It was also demonstrated 
that a balanced approach could be followed in a Merino stud, leading to an appreciable increase in liveweight, together with a reduction in fibre diameter, while keeping clean fleece weight constant (Olivier et al., 1995). These responses were achieved in spite of the unfavourable genetic correlation of clean fleece weight and liveweight with fibre diameter. The success of genetic improvement in these flocks in the last 50 years paved the way for the National Small Stock Improvement Scheme (NSSIS).

Table 1 Gross value of animal products in South Africa for 2010/2011 (Abstract of Agricultural Statistics, 2012)

\begin{tabular}{lrr}
\hline Product & $\begin{array}{r}\text { Gross value } \\
\text { (R 1 000 000) }\end{array}$ & \% of total \\
\hline Wool & 1675 & 2.37 \\
Mohair & 218 & 0.32 \\
Karakul pelts & 8 & 0.00 \\
Ostrich products & 399 & 0.58 \\
Poultry meat & 25069 & 37.04 \\
Eggs & 6676 & 9.96 \\
Beef and veal & 15037 & 22.22 \\
Sheep and goat meat & 3559 & 5.26 \\
Pork & 3027 & 4.47 \\
Fresh milk & 9114 & 13.47 \\
Other animal products & 2904 & 4.29 \\
\hline Total & 67686 & 100.00 \\
\hline
\end{tabular}

Initiation and expansion of small stock recording: Fleece testing of woolled sheep was a prerequisite for the genetic improvement of South African small stock (Erasmus \& Hofmeyr, 1984). Fleece testing has been present in one way or another since 1934. The National Fleece Testing Centre was established on Grootfontein Experimental Farm in 1965, using funds from the wool industry. Other institutions, such as the Wool Testing Bureau in Port Elizabeth, are currently also accredited to provide fleece testing services. The Small Stock Improvement Scheme was established formally in 1964. Initially, the focus was on resource flocks (Schoeman et al., 2010). Data were also recorded in several flocks maintained by commercial farmers, but research efforts were initially unsynchronized and therefore uncoordinated.

Progress with computer systems for data capturing and genetic evaluation, as well as electronic communication, made it easier to record data from throughout South Africa on central databases. The NSSIS was launched in the 1990s for woolled sheep and meat sheep (Schoeman et al., 2010; Cloete \& Olivier, 2010). Describing the aims of the NSSIS it was suggested that income per animal can be improved by increasing reproduction, shortening the production cycle and optimizing fibre traits in woolled sheep (Olivier, 1999). Efficient reproduction is determined by the number of lambs weaned, as well as weaning weight as an indicator of lamb quality. Growth is of paramount interest in shortening the production cycle, while fibre production depends on the quantity (fleece weight and clean yield), as well as the quality of wool (fibre diameter and coefficient of variation of fibre diameter as a proxy for staple strength). Reproduction and growth are emphasized in meat sheep, while fleece traits are considered in woolled sheep.

Cloete \& Olivier (2010) reported the breed distribution of the recorded portion of the South African small stock genetic resource, as represented by weaning weight records submitted to the NSSIS from 2005 to 2008. These figures were updated to the 2010 - 2011 weaning weight records, as a number of major changes seemed to have taken place. These percentages are presented in Figure 2. Merino weaning weight records are down from about $31 \%$ to $22 \%$ of the recorded portion of the local sheep population. Dorper records are accordingly down from $24 \%$ to $19 \%$ of the recorded population. Among the minor breeds, Ile de France records are down from $2.9 \%$ to $1.9 \%$, Merino Landsheep records from $1.6 \%$ to $1.0 \%$ and Van Rooy records from $0.8 \%$ to $0.6 \%$. SA Mutton Merino weaning weight records almost tripled from $6.1 \%$ to $18.1 \%$. Dohne Merino records increased from 24\% to $28 \%$, Dormer records from $6.0 \%$ to $7.1 \%$ and Meatmaster records from $0.8 \%$ to $2.3 \%$. The apparel wool breeds (Merino, Dohne Merino and SA Mutton Merino) contributed roughly $68 \%$ to the total number of records, while the meat breeds (Dorper, Meatmaster and Van 
Rooy) constituted about $22 \%$ of the records. The terminal sire breeds (Dormer, lle de France and Merino Landsheep) contributed the remaining $10 \%$ to the weaning weights recorded. Participation in the NSSIS was variable and ranged from $4.5 \%$ of registered breeders (Boer goats) to $73 \%$ (Dohne Merinos) (Schoeman et al., 2010). Cloete \& Olivier (2010) indicated that the most important breeds are adapted to the most vital production areas and occur throughout South Africa.

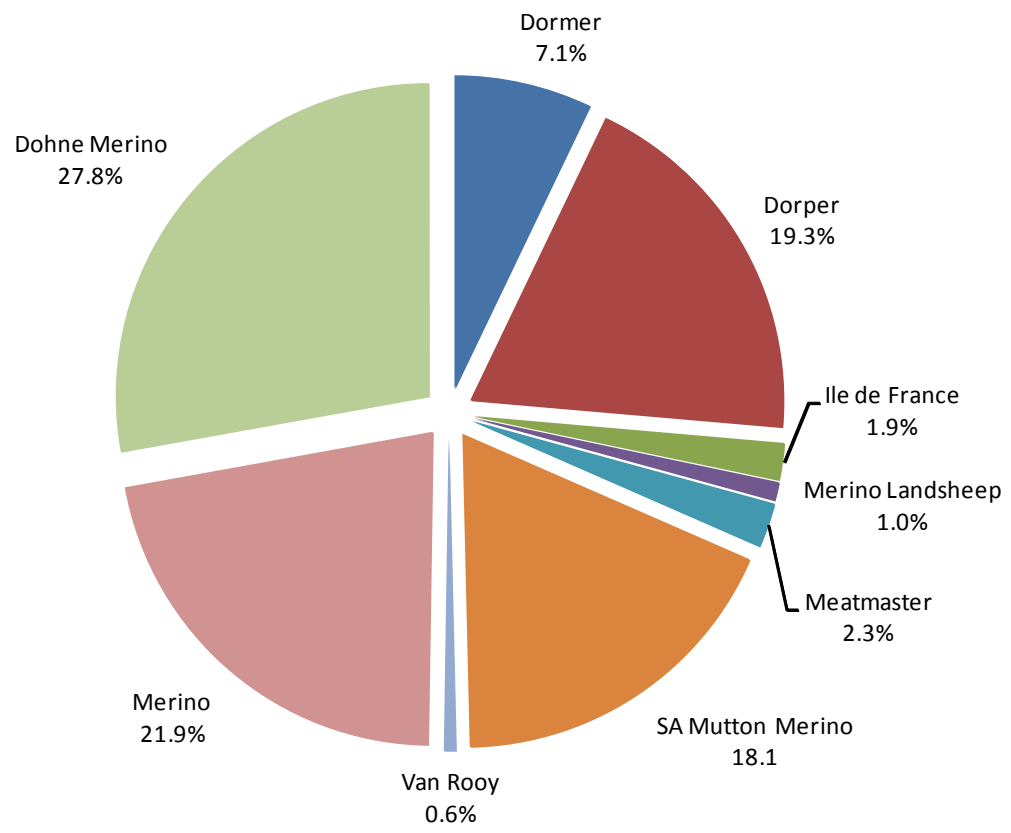

Figure 2 Pie chart depicting relative importance of various breeds as percentage of contributed weaning weights to National Small Stock Improvement Scheme (Olivier, 2014).

The change in small stock demographics with time validates further comment. Annual weaning weight records for the four dominant breeds (Dorper, Dohne Merino, SA Mutton Merino and Merino) for 2003 and 2012 are presented in Figure 3. Recording of lambs born in 2013 has not been completed, and it was decided to provide figures only up to 2012. It is evident that Dorper records increased substantially from a base of $\sim 5700$ records in $2003-2004$ to $\sim 22000$ in 2009. This increase was followed by a slump to $\sim 11000$ records in 2011 - 2012. This trend is possibly associated with the decision of the Dorper Breeders' Association in late 2010 to discontinue the compulsory recording of weaning weights in the breed. In contrast, recorded weaning weights in the SA Mutton Merino and Dohne Merino breeds increased from $\sim 10000$ and $\sim 8000$ in 2003 to $\sim 21000$ and 29000 in 2012, respectively. The recording of weaning weights was made compulsory in 2010 in the SA Mutton Merino and some backrecording of recent years was feasible. In the Dohne Merino, weaning weights were commonly recorded and used for preliminary index selection, but seldom submitted to the registration authority. Performance recording in this breed concentrated on yearling liveweight and fibre traits, as is evident from publications by Swanepoel (2006) and Van Wyk et al. (2008). However, birth registrations and weaning weights are used to generate reproduction records in the NSSIS. Given the importance of reproduction in small stock breeding (Olivier, 1999), Dohne Merino breeders increased their recording of weaning weights to include reproduction in their selection strategy (Olivier \& Cloete, 2011). In contrast with these breeds, the recording of weaning weights in the Merino breed was substantially more stable over time, the number of records accruing annually from $\sim 17000$ in 2003 to $\sim 23000$ in later years. The recording of weaning weights has always been voluntary in the Merino breed. It thus seems that a number of dedicated breeders who are committed to recording weaning weights supply a steady stream of records annually to the registration authority. 


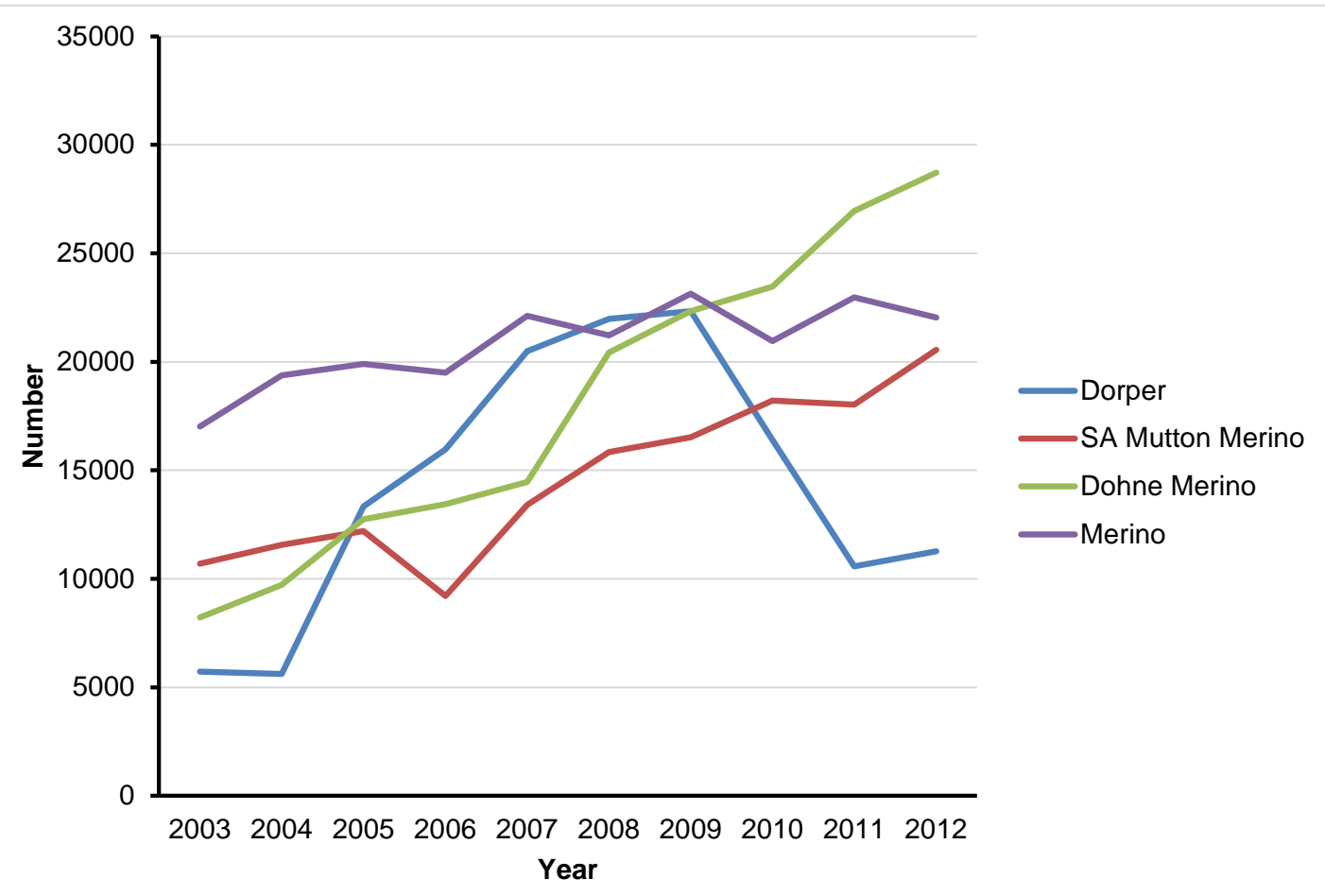

Figure 3 Line graph depicting annual number of weaning weights recorded officially for four major small stock breeds (Dorper, Dohne Merino, SA Mutton Merino and Merino) from 2003 to 2012 (Olivier, 2014).

The lack of integration of databases meant that genetic improvement initially depended on within-flock analyses (Delport et al., 2003), while sire referencing schemes (Groenewald et al., 1999), control tests (Poggenpoel \& Van der Merwe, 1992) and veld ram clubs (Olivier, 1999) were used for across-flock comparisons. The integration of data in the 1990s from various breeders in a common database for the important breeds resulted in the first across-flock genetic analysis for South African Merinos in 1998 (Olivier et al., 1998). Data from the scheme have since been used in across-flock analyses of several breeds, namely Dohne Merino (Van Wyk et al., 2008; Olivier \& Cloete, 2011), Merino (Olivier \& Cloete, 2007), Dormer, Ile de France and Merino Landsheep (Zishiri et al., 2014) and the Dorper (Olivier \& Cloete, 2006; Zishiri et al., 2013a). Research continues on these breeds, and the national analyses are improved as superior techniques and methods become available. Genetic trends in the major wool breeds are characterized by discernible objectives to increase liveweight, to increase or maintain fleece weight, and to reduce fibre diameter (Dohne Merino: Swanepoel, 2006; Merino: Olivier \& Cloete, 2007). Weight of lamb weaned per lambing opportunity also showed a discernible improvement in these breeds (Olivier \& Cloete, 2007; Olivier, 2014). In contrast, genetic trends for all traits in the Dorper breed are disappointing (Olivier \& Cloete, 2006; Zishiri et al., 2013b). Pre-weaning and weaning weights in the lle de France breed improved by $0.23 \%$ and $1.21 \%$ per annum, respectively, while weaning and post-weaning weights in the Dormer breed increased by $0.12 \%$ and $0.23 \%$ per annum, respectively (Zishiri et al., 2010). In contrast, no discernible genetic improvement was seen in the Merino Landsheep. There are marked differences between flocks in genetic trends, as could be expected. The best Merino flocks achieve gains comparable with those in research flocks, while no mentionable genetic progress was seen in the worst flocks (Table 2). Comparable differences between flocks can also be discerned in the other breeds constituting the NSSIS database (Olivier, 2014). However, these results have not been subjected to peer review and are not included in this review paper.

Worthwhile genetic improvement is thus discernible in some local small stock flocks. The local scheme was compared with a corresponding scheme in Australia by Cloete \& Olivier (2010). The evaluation of production traits compares favourably with the Australian scheme. However, the Australian scheme emphasizes traits associated with production costs, such as resistance to external and internal parasites, as well as scanned meat quality traits. It is also being adapted to incorporate genomic information (Rowe et al., 2013; Swan et al., 2014; Van der Werf et al., 2014). These options and research opportunities are not available in the local scheme, and are discussed below. 
Table 2 Annual genetic gain for traits in divergent Merino flocks based on genetic trends for relative economic value. Overall genetic trends for the breed are represented (adapted from Olivier \& Cloete, 2007)

\begin{tabular}{lccc}
\hline \multirow{2}{*}{ Trait } & \multicolumn{3}{c}{ Genetic trend (\% of overall mean) } \\
\cline { 2 - 4 } & Worst flock & Breed & Best flock \\
\hline Liveweight $(\mathrm{kg})$ & $0.01 \pm 0.06(0.02)$ & $0.24 \pm 0.01(0.52)$ & $0.50 \pm 0.07(2.09)$ \\
Clean fleece weight $(\mathrm{kg})$ & $-0.02 \pm 0.01(-0.54)$ & $-0.01 \pm 0.00(-0.24)$ & $0.03 \pm 0.01(0.73)$ \\
Staple length $(\mathrm{mm})$ & $0.18 \pm 0.07(0.17)$ & $0.20 \pm 0.02(0.19)$ & $0.77 \pm 0.21(0.74)$ \\
Fibre diameter $(\mu \mathrm{m})$ & $-0.06 \pm 0.01(-0.32)$ & $-0.08 \pm 0.01(-0.42)$ & $-0.09 \pm 0.03(-0.48)$ \\
Weight of lamb weaned $(\mathrm{kg})$ & $-0.08 \pm 0.05(-0.27)$ & $0.04 \pm 0.01(0.14)$ & $0.22 \pm 0.08(0.73)$ \\
\hline Relative economic value $(\mathrm{R})$ & $0.31 \pm 0.15$ & $1.17 \pm 0.05$ & $2.80 \pm 0.31$ \\
\hline
\end{tabular}

\section{Challenges to aligning small stock breeding in South Africa with international standards}

International livestock breeding showed marked advantages over the past few years. Trendsetting research has been done on the genomics of livestock and the breeding of livestock for resistance/tolerance to common pathogens. In fact, more than a third of the contributions at the 2010 World Congress on Genetics Applied to Livestock Production involved genomics in one form or another (Habier, 2010). Kahi (2010) noted that contributions from the developing world were underrepresented at this congress. It is therefore important to deliberate how the South African livestock industry and the NSSIS in particular shape up to accepted norms in developed countries. The environmental challenges to agriculture in South Africa (above) lead to a relatively poor production environment with low carrying capacity in most areas. There are also major differences between the pastoral areas that depend on natural veld and more intensive production areas, such as winter- and summer-rain pasture-cropping areas. Planning for the future is not possible without considering the matters stated above. It is foreseen that these challenges to robustness and adaptability of sheep can benefit from the discussion below. The contribution of ruminant livestock to the production of greenhouse gasses is seen as another challenge to small stock breeding in South Africa. However, this topic was reviewed recently by Du Toit et al. (2013). Aside from stating that this source indicated that small stock is an important contributor to enteric greenhouse gas production at $15.6 \%$ of all livestock emissions, this topic is not discussed further.

Genomic revolution: Technological improvement allows for traditional best linear unbiased prediction (BLUP) of estimated breeding values to be augmented by genomic information (GBLUP). Applications such as the whole genome sequencing of individuals, DNA-based marker systems and selection according to these markers could revolutionize animal breeding (Fan et al., 2010). High-density single nucleotide polymorphism (SNP) chips capable of genotyping thousands of markers, evenly distributed throughout the genome, are available for all mainstream livestock species. There is also a commercial SNP chip for sheep (Illumina 50K SNP beadchip), as used by Dodds et al. (2009), Magee et al. (2010) and Kijas et al. (2012). This chip contains approximately 54000 SNP markers distributed evenly across the genome. More than 49000 of these SNP markers have been demonstrated to occur in 75 economically important sheep breeds. Cattle have become the first livestock species to be fully sequenced (Bovine Hapmap Consortium, 2009) and several other livestock species have followed (Fan et al., 2010). Perez-Inciso (2010) suggested that whole genome information may be as important as SNP information at the present day and age.

Goddard et al. (2010) reviewed the methods applied to genomic information linked to phenotypic data. It is generally accepted that most quantitative traits are determined by many genes, each with a relatively small effect, in contrast to a small number of genes each of large effect (Goddard, 2011). Hayes et al. (2009) used BLUP, GBLUP and BayesA methods to estimate genomic breeding values for dairy bulls in the Australian progeny test. Compared with traditional breeding values based on pedigree records, the GBLUP method increased the accuracy of bulls for the progeny test from 0.38 to 0.44 for the Australian selection index, from 0.35 to 0.53 for the Australian profit ranking, from 0.28 to 0.45 for protein yield, from 0.20 to 0.29 for protein percentage and from 0.16 to 0.18 for fertility. The BayesA method resulted in further changes of $0.04,0.02,0.03,0.05$ and -0.04 , respectively. Researchers agree that genomic information can appreciably enhance genetic progress in the dairy industry (Hayes et al., 2009; Goddard et al., 2010; Weigel et al., 2010; Wiggans et al., 2010). 
Genotyping remains relatively expensive, and considerable research expenditure is needed to adapt this technology to the sheep industry. Weigel et al. (2010) stated that the cost of genotyping determines that only elite female animals may be genotyped in the dairy industry. However, genotyping is predicted to become more affordable in future, so that this may be a temporary obstacle. Benefits comparable with those in the dairy industry were foreseen in the Australian small stock industry (Van der Werf et al., 2009; 2011). Genomic selection was expected to yield lower benefits in meat and wool sheep compared with dairy cattle. The cost of genotyping is therefore a key concern when considering genomic selection of sheep (Daetwyler et al., 2010). Hayes et al. (2011) proposed that selection candidates should be genotyped with lower density SNP panels, followed by imputation of SNPs that had not been genotyped in an attempt to cut the costs. Imputing accuracy amounted to only 64\% in Merinos. However, these results were obtained with an $8 \mathrm{~K}$ chip, while results were improved substantially when a larger 12K chip (below) was used (Van der Werf, 2014). The smaller chip was sufficient to impute other breeds (Border Leicester, Poll Dorset and White Suffolk), with a smaller effective population size, to the $50 \mathrm{~K}$ chip with an accuracy of at least $80 \%$ (Hayes et al., 2011). The improved imputing performance in these breeds was attributed to higher levels of genetic relationships among rams in comparison with Merino rams. In addition, imputing accuracy depends on breed diversity and relies on the availability of genetically similar animals that have been genotyped for the maximum number of SNPS.

A large number of phenotypes linked to genotypic information is needed for an appropriate reference population. The ovine genetic resource consists of a number of specialized breeds (e.g. wool, meat, dualpurpose, maternal and terminal breeds). To overcome this constraint, the Information Nucleus Flock, which consists of a multi-breed reference population, was created in Australia (Van der Werf et al., 2009; 2010; Daetwyler et al., 2010; Hayes et al., 2011; Swan et al., 2012; Rowe et al., 2013). Correlations between genomic estimated breeding values and estimated breeding values ranged between 0.15 and 0.79 for wool traits and between -0.07 and 0.57 for meat traits (Daetwyler et al., 2010). The authors concluded that the current $50 \mathrm{~K}$ SNP marker density is not sufficient to allow accurate prediction equations to be transferred across breeds. This constraint can be mitigated through increasing the number of animals per breed in the reference population or increasing the marker density (Daetwyler et al., 2010). Despite these limitations, Van der Werf et al. (2011) reported that access to GEBVs could aid wool sheep by up to $30 \%$ in lifetime production (wool and lambs), and meat sheep by up to $20 \%$ in terms of meat and carcass quality that cannot be measured on live animals. Daetwyler et al. (2013) reported that GBLUP (based on dam trait deviations) increased the accuracy of genetic evaluation for number of lambs weaned from 0.19 to 0.21 in Merinos and from 0.15 to 0.19 in Border Leicesters. Further increases to 0.24 and 0.22 , respectively, were achieved when information on daughter trait deviations of rams were added. These references suggest that various ovine trait groups can benefit from genomic selection, which has been implemented successfully in Australia (Rowe et al., 2013; Swan et al., 2014; Van der Werf et al., 2014) and New Zealand (Auvray et al., 2014; Dodds et al., 2014). According to Rowe et al. (2013), a commercial service was implemented in 2013 in Australia, based on a $12 \mathrm{~K}$ standard density SNP chip for replacements, with some key sires genotyped at $50 \mathrm{~K}$. It will be interesting to determine whether similar advances would be feasible in South Africa.

Amid the hype about predicting genomic breeding values, Swan et al. (2012) stress that the challenges of the future will still be to collect phenotypes in sufficient numbers to allow accurate economic predictions. Another challenge is likely to be the management of vast volumes of data generated by the process of genomic prediction. A high-density $600 \mathrm{~K}$ beadchip was recently introduced for sheep (Hall, 2013). Anderson et al. (2013) used this particular chip to obtain an indication of SNPs associated with the yellow fat genotype in New Zealand sheep.

Molecular genetic information pertaining to the local small stock resource: Until recently, molecular genetic studies on the South African ovine resource centred on the use of 10 - 26 microsatellite markers to study breed diversity (Buduram, 2004; Soma et al., 2012) to characterize the Namaqua Afrikaner as a rare breed for conservation (Qwabe et al., 2012), and to relate an emerging breed (Meatmaster) to other local small stock genetic resources (Peters et al., 2010). The population structure of hardy Zulu sheep has also been characterized by using random amplified polymorphic DNA (RAPD) markers (Kunene et al., 2009). Recently SNP markers were used to compare the divergently selected Merino lines studied by Cloete et al. (2004). Sandenbergh et al. (2013) used the ovine SNP $50 \mathrm{~K}$ beadchip for this purpose. This study reported line differences at several loci on all 27 ovine chromosomes, depending on the method. A frequentist method identified 926 loci under selection in the lines after the results had been corrected for multiple testing. The more stringent Bayesian test identified 47 loci under selection, including a marker near to the corticotrophin releasing hormone on ovine chromosome 9 (Sandenbergh et al., 2013). This result is interesting given the indications that the lines under study differed in their ability to synthesize cortisol (Hough et al., 2013). 
Sandenbergh et al.'s (2013) results support previous line differences based on RAPD markers in the same lines (Naidoo et al., 2005).

International trends are focused on enhancing traditional breeding values with genomic information (discussed above). The prediction of genomic breeding values for South African livestock has not been accomplished, although a framework to achieve this for the beef and dairy industries has been drawn up by Van Marle-Köster et al. (2013b). Other livestock species were included in a subsequent contribution by Van Marle-Köster et al. (2013a). It is reasoned that the same sort of advantages as discussed by Rowe et al. (2013) and Swan et al. (2014) for the Australian sheep industry and by Auvray et al. (2014) for the New Zealand sheep industry can be achieved in the South African industry, provided that the appropriate research is conducted. A reference population consisting of appreciable numbers of animals (at least thousands) needs to be genotyped and phenotyped for such a project to succeed. The animals contributing to the reference population should be chosen to gain the maximum amount of information at the lowest cost. The Information Nucleus Flock in Australia contributed markedly to genomic prediction by providing genotyped animals with extended phenotypic information over many trait groups (production, reproduction, disease resistance and meat quality) in an extensively genotyped population (Van der Werf et al., 2010; Rowe et al., 2013; Swan et al., 2014). Although the local industry cannot rely on a genetic resource of this nature and scope, suitable animal genetic resources are available in the most important genetic resource flocks described by Schoeman et al. (2010). At least some of these flocks are still being maintained and a wide range of additional phenotypes is recorded in these genetic resource flocks. It is easy to genotype such animals with the ovine SNP $50 \mathrm{~K}$ beadchip, as was done by Sandenbergh et al. (2013). Since these flocks have genetic linkages to the recorded animals in the NSSIS, information of such animals could be combined with influential animals with genotypes and complete phenotypic records in the NSSIS to form the basis of genomic prediction. This reasoning is consistent with arguments presented by Van der Werf et al. (2011) and Auvray et al. (2014) that resource flocks containing multiple bloodlines or widely divergent animals resulting from different selection strategies may aid genomic selection by more accurately representing those multiple lineages contained in the commercial population. A project with this as the main objective is currently being planned by the role-players involved in the genetic improvement of sheep. Since reproduction has been identified as a key trait in local sheep flocks (Olivier, 1999), it is reassuring that Daetwyler et al. (2014) reported that genomic prediction accuracies, albeit fairly low, can be enhanced by a combined reference population consisting of genotyped ewes with phenotypes and genotyped sires with well-recorded daughters.

Resistance to stressors: The varied environmental conditions supporting ovine wool and meat production in South Africa result in the animals being subjected to a number of stressors. This review emphasizes internal and external parasites. Evidently many international papers have commented on these challenges. Since the objective of this paper is to draw attention to parallel studies in South Africa, it is not seen as an exhaustive review of international literature. However, linkages to international literature are provided where appropriate.

Consistent natural challenge by internal helminthic parasites of sheep is complicated by the relatively dry conditions in most parts of the Karoo. However, Snyman (2007) reported genetic variation in sheep to wire worm (Haemonchus contortus) by using artificial challenge. Natural challenges may be used to select sheep for resistance to internal parasites under conditions where sufficient natural challenge prevails. Genetic variation in parasite burdens, as reflected by faecal worm egg counts, was demonstrated in the more temperate Mediterranean areas (Cloete et al., 2007). Matebesi-Ranthimo et al. (2014) reported that genetic correlations of helminthic faecal worm egg counts with wool traits were mostly favourable. These results suggest that selection for resistance to gastro-intestinal helminths is unlikely to affect wool traits adversely. Data on faecal worm egg counts in Australian flocks, where adequate levels of natural challenge prevail, are available in the Sheep Genetics Australia database (Khusro et al., 2004). The identification of sires with an increased level of resistance to gastro-intestinal helminthic parasites is thus feasible in this scheme. It ought to be viable to adapt the NSSIS to provide comparable results to participants farming under conditions where adequate natural challenge with gastro-intestinal helminths occurs.

Research by Scholtz et al. (2010b; 2013a) suggested sufficient genetic variation on the underlying liability scale where breech flystrike of Merinos is concerned. The presence of significant genetic variation in breech strike is supported by marked line differences in its frequency in lines of Merino sheep divergently selected for number of lambs weaned per ewe joined (Scholtz et al., 2010a). The frequency of breech strike in more wrinkly animals selected against reproduction rate was between fourfold and tenfold higher than in plainer animals selected for an improved reproduction rate. The adequate challenge of animals with flystrike is not ethically responsible because of animal welfare concerns. It will thus be of value to identify indirect selection criteria to identify animals less likely to be affected by breech strike. Traits that can be recorded on all animals that were favourably related to breech strike under local conditions were wrinkle scores (Scholtz 
et al., 2010b; 2013a) and dag score (Scholtz et al., 2013a). The line differences in the prevalence of breech strike between lines selected for and against reproduction were supported by more favourable breech characteristics in the line selected for reproduction as far as wrinkles, dag scores (Scholtz et al., 2011b; 2012) and a larger bare area around the perineum were concerned (Scholtz et al., 2011b). Plainer animals with lower dag scores that were selected for reproduction took a shorter period to crutch than more wrinkly and daggy animals selected against reproduction. These results support findings of a much more elaborate study published by Greeff et al. (2013) in Australia. The national Sheep Genetics Australia database makes provision for the routine publishing of breeding values for breech strike indicator traits (Brown et al., 2010). Similar results are not available in the NSSIS, but trends in the South African wool industry already favour plainer animals, as noted by Olivier (1999). The local industry appears to react to this challenge, albeit mostly in response to the well-known adverse genetic relationship of wrinkles with reproduction (Atkins, 1980; Cloete et al., 2005).

There is an international paucity of research on ovine tick resistance/tolerance. However, preliminary local research suggested that indigenous Namaqua Afrikaner sheep had lower tick loads on the udder and hind legs than commercial Dorper and SA Mutton Merino (Cloete et al., 2013a). Namaqua Afrikaner ewes had better scores for udder health than the other breeds, particularly later in life. Subjective udder scores and hind leg tick counts were highly repeatable ( 0.75 and 0.48 , respectively). There was also a significant correlation between animal effects for tick counts and udder scores. These preliminary results suggest that resistance to tick infestation in sheep may be heritable, and that high tick loads may impair udder health. This contention is supported by significant genetic variation in tick counts in Bonsmara cattle (Budeli et al., 2009). However, these authors did not comment on possible relations with udder health. Further research is thus needed to better understand factors associated with tick load in the ovine genetic resource.

Resistance to pathogens is typically a trait that is likely to benefit from marker-assisted selection. If more resistant animals can be identified by markers, possibly during the process of genomic selection, it will render the challenge of selection candidates by that specific pathogen unnecessary. This will go a long way towards addressing legitimate ethical concerns about challenge-based methods currently being used during selection for disease resistance. Disease resistance traits are therefore commonly cited as being likely to benefit largely from genomic selection (Scholtz et al., 2013b).

Local capacity: Livestock breeding in the developed world benefits from genomic selection. But will these technologically advanced solutions be affordable in South Africa, since the percentage of the gross domestic product (GDP) invested in research locally is appreciably less than in developed countries (Cloete, 2012)? Countries in the BRICS (Brazil, Russia, India, China and South Africa) group invest between $0.71 \%$ (India) and $1.49 \%$ (China) of their GDP in research, compared with an average of $2.26 \%$ for countries in the Organization for Economic Cooperation and Development (OECD) (OECD, 2009). At 0.92\% of GDP, South African investment in research is intermediate in the grouping (Anon, 2009). Sweden invests as much as $3.63 \%$ of its GDP in research (OECD, 2009). Only Russia, China and South Africa feature in the most recent OECD statistics; 2011 being the most recent record for South Africa (OECD StatExtracts, 2014). According to this source, investment in research in 2011 relative to national GDP amounted to 1.84\% for China, 1.09\% for the Russian Federation, and $0.76 \%$ for South Africa. In contrast, the OECD invested $2.40 \%$ of GDP in research and Sweden 3.41\%. Research expenditure in China grew, whereas it dwindled in South Africa. The total amount invested in research in South Africa was approximately R 21 billion (Anon, 2009). Research and development in agriculture contributed between $5.5 \%$ and $6.9 \%$ to the total research budget from 2007 - 2008 to 2009 - 2010 (Anon, 2009; Mjwara et al., 2013). This amount took seventh place, behind engineering, natural sciences, medical and health sciences, information and communication sciences, social sciences and humanities, and applied sciences and technology (Figure 3).

Human capacity to apply these developments warrants attention. The number of researchers per 1000 population in South Africa was approximately 1.5 (OECD, 2009). Corresponding figures in the developed world ranged from 3.6 in Italy to 15.7 in Finland, with an average of 7.3 researchers per 1000 population in OECD countries. The most recent OECD statistics for 2011 suggested that the number of researchers in South Africa remained stable at 1.5 researchers per 1000 employed population members (OECD StatExtracts, 2014). In contrast, comparable values for OECD countries generally increased, with a range from 4.2 in Portugal to 15.9 in Finland and an OECD average of 7.7. South Africa therefore needs to work on its capacity to undertake this high-level research. 


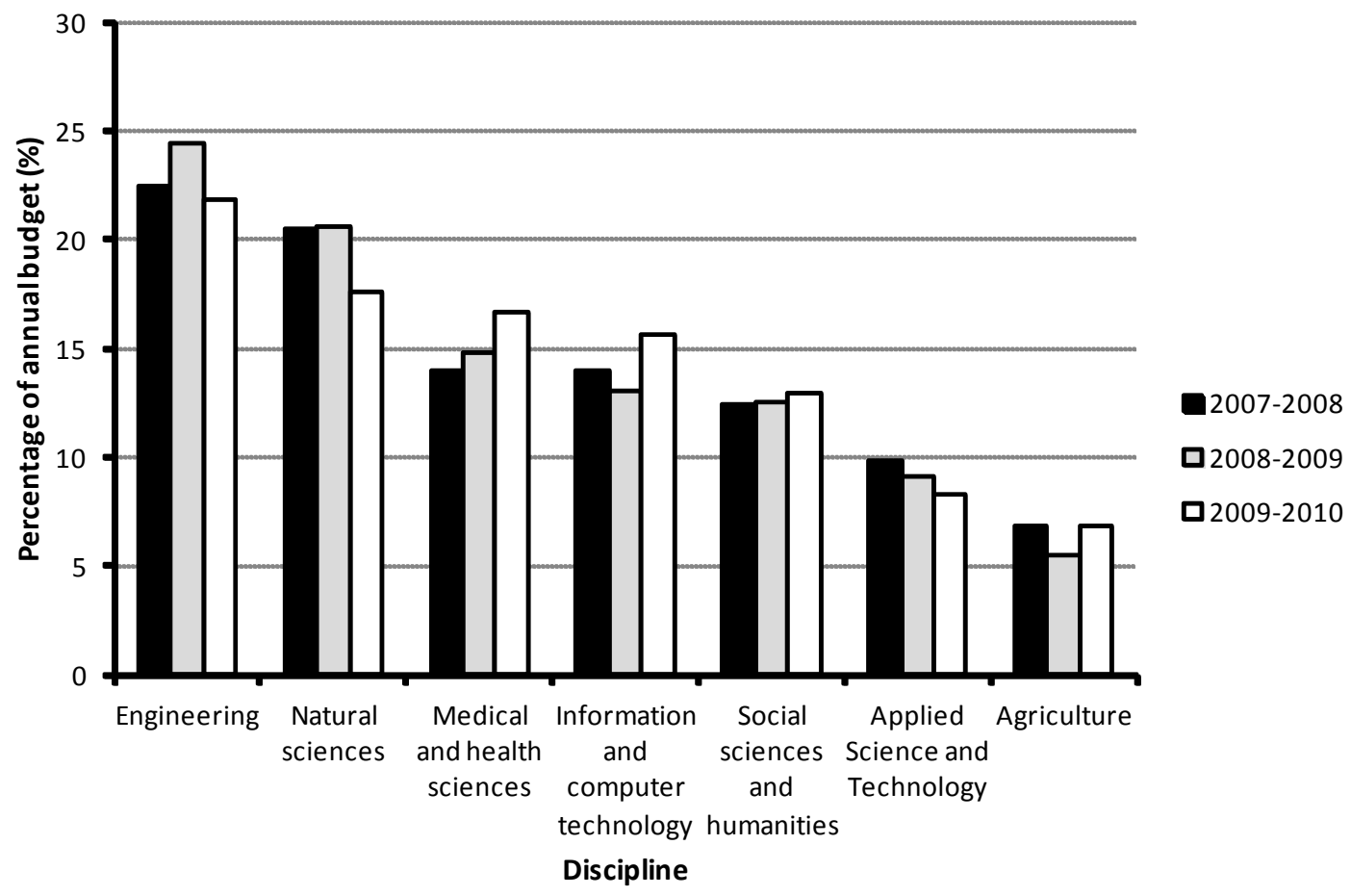

Figure 3 Relative contribution of funding for various disciplines to national research and development budget in South Africa for 2007 - 2008 to 2009 - 2010 (adapted from Anon., 2009, Mjwara et al., 2013).

South Africa faces challenges in terms of funding high-level research, and the human capacity to implement it. Against this background, it is essential to ensure that strategic research is conducted, while alliances among local science and technology groups, as well as with overseas collaborators and institutions, may assist in alleviating capacity problems.

Funding of possible research on the genomic evaluation of the local ovine genetic resource should be considered next. Developed countries concede that the cost of genotyping is too much for a single organization to bear (Pollak at al., 2012), and this reality should apply to a greater extent in South Africa. Local role-players involved in recording sheep data should collaborate to ensure that research and development take place so that the provision of genomic breeding values to local sheep breeders becomes a reality.

\section{Conclusions}

This review stressed the institutional capacity that is available to support the sheep industry. The infrastructure to allow purposeful breeding and selection of sheep is present in the NSSIS. However, it is possible to improve on the existing service and to extend it to more producers.

There are obvious challenges for sheep breeding that need to be overcome in future. Substantial investment in the local capacity in terms of funding and manpower is needed for South Africa to share in the technological advances of modern animal breeding. Limited funds for agricultural research should urge researchers to focus on relevant issues, while unnecessary competition among institutions should be discouraged. It will not benefit industry if this limited capacity in human resources is fragmented. Strategic alliances with international institutions and scientists could alleviate human capacity problems.

\section{Acknowledgements}

Several colleagues and postgraduate students contributed to this review, and their contributions are acknowledged with gratitude. The bulk of research leading to this paper was funded jointly by the South African Wool Industry, the Western Cape Agricultural Research Trust, and THRIP initiative of the National Research Foundation.

\section{References}


Abstract of Agricultural Statistics, 2012. Accessed from: http://www.nda.agric.za/docs/statsinfo/Ab2012.pdf on 20 March 2014. Directorate: Agricultural Information Services, Pretoria, South Africa.

AGIS, 2007a. Agricultural Geo-Referenced Information System, accessed from: www.agis.agric.za on 20 March 2014. Annual rainfall - Annual rainfall. Available from: http://www.agis.agric.za/agisweb/nr_atlas?rb=nr_atlas_ann_rainfall.

AGIS, 2007b. Agricultural Geo-Referenced Information System, accessed from: www.agis.agric.za on 20 March 2014. Land Capability - Other land categories. Available from: http://www.agis.agric.za/agisweb/nr_atlas?rb=nr_atlas_land_cap.

AGIS, 2007c. Agricultural Geo-Referenced Information System, accessed from: www.agis.agric.za on 20 March 2014. Agricultural enterprises - Agricultural regions. Available from: http://www.agis.agric.za/agisweb/\$WEB_HOME?Mlval=content2_h.html\&id=nr_atlas_agric_regions (accessed on 4 February 2009).

Anderson, R., McEwan, J., Brauning, R., Kijas, J., Dalrymple, J., Worley, K., Daetwyler, H., Van Stijn, T., Clarke, S., Baird, H. \& Khan, A., 2014. Development of a high density (600K) Illumina ovine SNP chip and its use to fine map the yellow fat locus. Accessed from: https://pag.confex.com/pag/xxii/webprogram/Paper10725.html on 20 March 2014.

Anon., 2009. SAccess - ACCESS4EU - South Africa (Contract Number 243851) "Supporting the EU access to South Africa's research and innovation programmes. Report on South African Research and innovation capacity. Accessed from http://www.esastap.org.za/download/sa_ri_capacity.pdf on 20 March 2014.

Atkins, K.D., 1980. Selection for skin folds and fertility. Proceedings of the Australian Society for Animal Production 13, 174-176.

Auvray, B., McEwan, J.C., Newman, S.-A.N., Lee, M. \& Dodds, K.G., 2014. Genomic prediction of breeding values in the New Zealand sheep industry using a 50K SNP chip. J. Anim. Sci., in press. Accessed from http://www.journalofanimalscience.org/content/early/2014/08/22/jas.2014-7801.full.pdf+html on 15 September 2015.

Brown, D.J., Swan, A.A. \& Gill, J.S., 2010. Within- and across-flock genetic relationships for breech flystrike resistance indicator traits. Anim. Prod. Sci. 50, 1060-1068.

Budeli, M.A., Nephawe, K.A., Norris, D., Selapa, N.W., Bergh, L. \& Maiwashe, A., 2009. Genetic parameter estimates for tick resistance in Bonsmara cattle. S. Afr. J. Anim. Sci. 39, 321-327.

Buduram, P., 2004. Genetic characterization of southern African sheep breeds using DNA markers. M.Sc. (Agric.) thesis, University of the Free State, Bloemfontein, South Africa.

Cloete, S.W.P., 2012. Breeding in developing countries and tropics. Encyclopedia of Sustainability, Science and Technology. Ed: Meyers, R.A., Springer Science and Business Media. DOI 10.1007/978-1-44190851-3. Pages 1740-1795.

Cloete, S.W.P. \& Olivier, J.J., 2010. South African Sheep and Wool Industry. In: The International Sheep and Wool Handbook. Ed: Cottle, D.J., Nottingham University Press, Manor Farm, Thrumpton, Nottingham NG11 OAX, United Kingdom. pp. 95-112.

Cloete, S.W.P., Olivier, J.J., Snyman, M.A. \& Du Toit, E., 1998. Genetic parameters and trends in a selection experiment for increased clean fleece weight involving South African Merinos. Aust. J. Exper. Agric. 38, 427-432.

Cloete, S.W.P., Gilmour, A.R., Olivier, J.J. \& Van Wyk, J.B., 2004. Genetic and phenotypic trends and parameters in reproduction, greasy fleece weight and live weight in Merino lines divergently selected for multiple rearing ability. Aust. J. Exper. Agric. 44, 745-754.

Cloete, S.W.P., Olivier, J.J., Van Wyk, J.B., Schoeman, S.J. \& Erasmus, G.J., 2005. Genetic parameters and trends for hogget traits in Merino lines divergently selected for multiple rearing ability. Proceedings of the Association for the Advancement of Animal Breeding and Genetics 16, 24-27.

Cloete, S.W.P., Olivier, J.J., Du Toit, E. \& Dreyer, F.H., 2007. Genetic analysis of faecal worm egg count in South African Merinos under natural challenge. S. Afr. J. Anim. Sci. 37, 237-247.

Cloete, J.J.E., Cloete, S.W.P., Scholtz, A.J. \& Matthee, S., 2013a. The effect of breed, ewe age and season on tick counts of indigenous and commercial sheep in South Africa. Proceedings of the Association for the Advancement of Animal Breeding and Genetics 20, 187-190.

Cloete, S.W.P., Olivier, J.J. \& Du Toit, E., 2013b. Genetic trends in a Merino line selected for a reduced fibre diameter relative to an unselected control flock. Proceedings of the Association for the Advancement of Animal Breeding and Genetics 20, 377-380.

Daetwyler, H.D., Hickey, J.M., Henshall, J.M., Dominik, S., Gredler, B., Van der Werf, J.H.J. \& Hayes, B.J., 2010. Accuracy of estimated genomic breeding values for wool and meat traits in a multi-breed sheep population, Anim. Prod. Sci. 50, 1060-1068. 
Daetwyler, H.D., Bolormaa, S., Brown, D.J., Van der Werf, J.H.J. \& Hayes, B.J., 2013. A genomic prediction cross-validation approach combining ewe repeated phenotypes and ram daughter trait deviations. Proceedings of the Association for the Advancement of Animal Breeding and Genetics 20, 360-363.

Daetwyler, H.D., Bolormaa, S., Kemper, K.E., Brown, D.J., Swan, A.A., Van der Werf, J.H.J. \& Hayes, B.J., 2014. Using genomics to improve reproduction in sheep. Proceedings of the $10^{\text {th }}$ World Congress on Genetics Applied to Livestock Production. Accessed from https://asas.org/docs/default-source/wcgalpproceedings-oral/156_paper_10358_manuscript_1334_0b.pdf?sfvrsn=2 on 15 September 2014.

Delport, G.J., Van Wyk, J.B. \& Hunlun, C., 2003. BLUP - Breeding values for breed evaluation. Dohne Merino Journal 27 (1), 42-49.

Dodds, K.G., Auvray, B., Pickering, N. \& McEwan, J.C., 2009. Quality control for ovine SNP50 beadchip genotypes. Proceedings of the Association for the Advancement of Animal Breeding and Genetics 18, 296-299.

Dodds, K.G., Auvray, B., Lee, M., Newman, S.-A.N. \& McEwan, J.C., 2014. Genomic selection in New Zealand dual purpose sheep. Proceedings of the $10^{\text {th }}$ World Congress on Genetics Applied to Livestock Production. Accessed from: https://asas.org/docs/default-source/wcgalp-proceedingsoral/333_paper_10352_manuscript_1331_0.pdf?sfvrsn=2 on 15 September 2014.

Du Toit, C.J.L., Van Niekerk, W.A. \& Meissner, H.H., 2013. Direct greenhouse gas emissions of the South African small stock sectors. S. Afr. J. Anim. Sci. 43, 340-361.

Erasmus, G.J. \& Hofmeyr, J.H., 1984. The development of performance recording programmes for woolled sheep in South Africa. Proceedings of the 2nd World Congress on Sheep and Beef Cattle Breeding, 16-19 April 1984, Pretoria. Eds: Hofmeyr, J.H. \& Meyer, E.H.H., South African Stud Book and Livestock Improvement Association, Bloemfontein. pp. 399-412.

Fan, B., Du, Z.-Q., Gorbach, D.M. \& Rothschild, M.F., 2010. Development and application of high-density SNP arrays in genomic studies of domestic animals. Asian-Austral. J. Anim. Sci. 23, 833-847.

Goddard, M.E., 2011. Genetic architecture of complex traits. Proceedings of the Association for the Advancement of Animal Breeding and Genetics 19, 1-6.

Goddard, M.E., Hayes, B.J. \& Meuwissen, T.H.E., 2010. Genomic selection in farm animal species Lessons learn and future perspectives. Proceedings of the $9^{\text {th }}$ World Congress on Genetics Applied to Livestock Production, 1-6 August 2010, Leipzig, Germany. ISBN 978-3-00-031608-1. Available at: http://www.kongressband.de/wcgalp2010/assets/pdf/0701.pdf (8 pages).

Greeff, J.C., Karlsson, L.J.E. \& Schlink, A.C., 2014. Identifying indicator traits for breech strike in Merino sheep in a Mediterranean environment. Anim. Prod. Sci. 54, 125-140.

Groenewald, P.G.J., Olivier, J.J. \& Olivier, W.J., 1999. Heritability estimates for Merino sheep obtained from a national progeny test. S. Afr. J. Anim. Sci. 29, 174-178.

Habier, D., 2010. More than a third of the WCGALP presentations on genomic selection. J. Anim. Breed. Genet. 127, 336-337.

Hall, G., 2013. Chip spans the gap. Country Wide, November 2013, 86-87.

Hayes, B.J., Bowman, P.J., Chamberlain, A.J. \& Goddard, M.E., 2009. Invited review: Genomic selection in dairy cattle: progress and challenges. J. Dairy Sci. 92, 433-443.

Hayes, B.J., Bowman, P.J., Daetwyler, H.D., Kijas, J.W. \& Van der Werf, J.H.J., 2011. Accuracy of genotype imputation in sheep breeds. Anim. Genet. 43, 72-80.

Hough, D., Swart, P. \& Cloete, S., 2013. Exploration of the Hypothalamic-Pituitary-Adrenal axis to improve animal welfare by means of genetic selection: Lessons from the South African Merino. Animals 3, 442-474.

Kahi, A.K., 2010. Developing countries and the 9th World Congress on Genetics Applied to Livestock Production. J. Anim. Breed. Genet. 127, 333.

Khusro, M., Van der Werf, J.H.J., Brown, D.J. \& Ball, A., 2004. Across flock (co)variance components for faecal worm egg count, live weight, and fleece traits for Australian Merinos. Livest. Prod. Sci. 91, 35-43.

Kijas, J.W., Lenstra, J.A., Hayes, B., Boitard, S., Porto Neto, L.R., Cristobal, M.S., Servin, B., McCulloch, R., Whan, V., Gietzen, K., Paiva, S., Barendse, W., Ciani, E., Raadsma, H., McEwan, J., Dalrymple, B., and other members of the International Sheep Genomics Consortium, 2012. Genome-wide analysis of the world's sheep breeds reveals high levels of historic mixture and strong recent selection. PloS Biology 10, e1001258.

Kunene, N.W., Bezuidenhout, C.C. \& Nsahlai, I.V., 2009. Genetic and phenotypic diversity in Zulu sheep populations: implications for exploitation and conservation. Small Rumin. Res. 84, 100-107.

Magee, D.A., Park, S.D.E., Scraggs, S., Murphy, A.M., Doherty, M.L. \& Kijas, J.W., International Sheep Genomics Consortium \& MacHugh, D.E., 2010. High fidelity of whole-genome amplified sheep (Ovis 
aries) deoxyribonucleic acid using a high-density single nucleotide polymorphism array-based genotyping platform. J. Anim. Sci. 88, 3183-3186.

Matebesi-Ranthimo, P.A.M., Cloete, S.W.P., Van Wyk, J.B. \& Olivier, J.J., 2014. Genetic parameters and relationships of faecal worm egg count with objectively measured wool traits in the Tygerhoek Merino flock. S. Afr. J. Anim. Sci. 44, 178-188.

Meissner, H.H., Scholtz, M.M. \& Palmer, A.R., 2013. Sustainability of the South African Livestock Sector towards 2050. Part 1: Worth and impact of the sector. S. Afr. J. Anim. Sci. 29, 174-178.

Mjwara, P., Patel, I., Blankley, W., Mamagobo, T., Labadarios, D. \& Mashamba, G., 2013. National survey of research and experimental development (2009/10 Fiscal Year): high-level key results. HSRC Library: shelf number 7589, Accessed from http://www.hsrc.ac.za/en/research-outputs/view/6239 on 20 March 2014.

Naidoo, P., Cloete, S.W.P. \& Fossey, A., 2005. South African Merinos divergently selected for multiple rearing ability: a preliminary study of divergence based on RAPD markers. Proc. Assoc. Advmnt. Anim. Breed. Genet. 16, 254-257.

Neser, F.W.C., Konstantinov, K.V. \& Erasmus, G.J., 1995. Estimated genetic trends for weaning weight in three Dorper lines with different selection criteria. S. Afr. J. Anim. Sci. 25, 13-15.

OECD, 2009. OECD Factbook 2009: Economic, Environmental and social statistics. ISBN 92-64-05604-1. 2 Rue André-Pascal, 75775 Paris, France.

Olivier, J.J., 1999. The South African Merino performance testing scheme. In: 'Rising to the challenge Breeding for the $21^{\text {st }}$ Century Customer'. Beef Industry and CRC for Premium Quality Wool Industry Symposia. Supplement to the Proceedings of the Association for the Advancement of Animal Breeding Genetics 13, 119-124.

Olivier, J.J., 2014. Unpublished data. Directorate Animal Sciences: Elsenburg, Elsenburg, South Africa, e-mail contact details: bukso@elsenburg.com.

Olivier, J.J. \& Cloete, S.W.P., 2006. Genetic analysis of the South African Dorper sheep. Proceedings of the $7^{\text {th }}$ World Congress on Genetics Applied to Livestock Production, Bello Horizonte, Brazil. Communication 04-10.

Olivier, J.J. \& Cloete, S.W.P., 2007. Genetic change in some South African Merino studs participating in the Merino plan. Proceedings of the Association for the Advancement of Animal Breeding and Genetics $17,324-327$.

Olivier, J.J. \& Cloete, S.W.P., 2011. Genetic (co)variances for yearling traits and reproduction in the South African Dohne Merino breed. Proceedings of the Association for the Advancement of Animal Breeding and Genetics 19, 167-170.

Olivier, J.J., Erasmus, G.J., Van Wyk, J.B. \& Konstantinov, K.V., 1995. Response to selection for BLUP of breeding values in the Grootfontein Merino stud. S. Afr. J. Anim. Sci. 25, 13-15.

Olivier, J.J., Yurgens, Y., Mostert, B.E. \& Erasmus, G.J., 1998. Across-stud evaluation of Merinos in South Africa. Proceedings of the $6^{\text {th }}$ World Congress on Genetics Applied to Livestock Production 24, 11-14.

Perez-Enciso, M., 2010. Leipzig: The dawn of the genomes era. J. Anim. Breed. Genet. 127, 338.

Peters, F., Kotze, A., Van der Bank, F.H. \& Grobler, J.P., 2010. Genetic profile of the locally developed Meatmaster sheep breed in South Africa based on microsatellite analysis. Small Rumin. Res. 90, 101-108.

Poggenpoel, D.G. \& Van der Merwe, C.A., 1992. Between flock genetic differences in 40 Merino studs. S. Afr. J. Anim. Sci. 175-180.

Pollak, E.J., Bennett, G.L., Snelling, W.M., Thallman, R.M. \& Kuehn, L.A., 2012. Genomics and the global beef cattle industry. Anim. Prod. Sci. 52, 92-99.

Qwabe, S.O., Van Marle-Köster, E. \& Visser, C., 2012. Genetic diversity and population structure of the endangered Namaqua Afrikaner Sheep. Trop. Anim. Health Prod. 45, 511-516.

Rowe, J.B., Gill, S., Banks, R.G. \& Van der Werf, J.H.J., 2013. Genomics for the Australian sheep industry: from design to delivery. Proceedings of the Association for the Advancement of Animal Breeding and Genetics 20, 14-17.

Rust, J.M. \& Rust, T., 2013. Climate change and livestock production: A review with emphasis on Africa. S. Afr. J. Anim. Sci. 43, 255-267.

Sandenbergh, L., Roodt-Wilding, R., Van der Merwe, A.E. \& Cloete, S.W.P., 2013. Analysis of a South African Merino flock divergently selected for reproductive potential. Proceedings of the Association for the Advancement of Animal Breeding and Genetics 20, 98-101.

Schoeman, S.J., Cloete, S.W.P. \& Olivier, J.J., 2010. Returns on investment in sheep and goat breeding in South Africa. Livest. Sci. 130, 70-82. 
Scholtz, A.J., Cloete, S.W.P., Van Wyk, J.B., Kruger, A.C.M. \& Van der Linde, T.C.de K., 2010a. Influence of divergent selection for reproduction on the occurrence of breech strike in mature Merino ewes. Anim. Prod. Sci. 50, 203-209.

Scholtz, A.J., Cloete, S.W.P., Van Wyk, J.B., Misztal, I., Du Toit, E. \& Van der Linde, T.C.deK., 2010b. Genetic (co)variances between wrinkle score and absence of breech strike in mulesed and unmulesed Merino sheep, using a threshold model. Anim. Prod. Sci. 50, 210-218.

Scholtz, A.J., Cloete, S.W.P., Cloete, J.J.E., Kruger, A.C.M., Van Wyk, J.B. \& Van der Linde, T.C.deK., 2011. Genetic parameters for breech strike indicator traits and yearling production traits in Merinos. Proceedings of the Association for the Advancement of Animal Breeding and Genetics 19, 175-178.

Scholtz, A.J., Cloete, S.W.P., Cloete, J.J.E., Kruger, A.C.M., Van Wyk, J.B. \& Van der Linde, T.C.deK., 2012. Divergent selection for reproduction affects dag score, breech wrinkle score and crutching time in Merinos. S. Afr. J. Anim. Sci. 42, 274-279.

Scholtz, A.J., Cloete, S.W.P., Van Wyk, J.B. \& Du Toit, E., 2013a. Genetic analysis of absence of breech strike and breech strike indicator traits in South African Merino sheep. Proceedings of the Association for the Advancement of Animal Breeding and Genetics 20, 459-462.

Scholtz, M.M., Maiwashe, A., Neser, F.W.C., Theunissen, A., Olivier, W.J., Makolobate, M.C. \& Hendriks, J., 2013b. Livestock breeding for sustainability to mitigate global warming, with emphasis on the developing countries. S. Afr. J. Anim. Sci. 43, 270-281.

Soma, P., Kotze, A., Grobler, J.P. \& Van Wyk, J.B., 2012. South African sheep breeds: Population genetic structure and conservation implications. Small Rumin. Res. 103, 112-119.

Snyman, M.A., 2007. Prospects for the utilization of variation in parasite resistance among individual sheep within a flock. Grootfontein Agric. 7 (1), 29-34.

Swan, A.A., Johnston, D.J., Brown, D.J., Tier, B. \& Graser, H.-U., 2012. Integration of genomic information into beef cattle and sheep genetic evaluations in Australia. Anim. Prod. Sci. 52, 126-132.

Swan, A.A., Brown, D.J., Daetwyler, H.D., Hayes, B.J., Kelly, M., Moghadder, M. \& Van der Werf, J.H.J., 2014. Genomic Evaluations in the Australian Sheep Industry. Proceedings of the $10^{\text {th }}$ World Congress on Genetics Applied to Livestock Production. Accessed from https://asas.org/docs/defaultsource/wcgalp-proceedings-oral/334_paper_10482_manuscript_1357_0.pdf?sfvrsn=2 on 15 September 2014.

Swanepoel, J.W., 2006. A genetic evaluation of the Dohne Merino breed in South Africa. M.Sc. (Agric.) thesis, University of the Free State, Bloemfontein.

Van der Werf, J.H.J., 2009. Potential benefit of genomic selection in sheep. Proceedings of the Association for the Advancement of Animal Breeding and Genetics 18, 38-41.

Van der Werf, J.H.J., 2014. Personal communication. University of New England, Armidale NSW, Australia, e-mail contact details: jvanderw@une.edu.au.

Van der Werf, J.H.J., Kinghorn, B.P. \& Banks, R.G., 2010. Design and role of an information nucleus in sheep breeding programs. Anim. Prod. Sci. 50, 998-1003.

Van der Werf, J.H.J., Horton, B.J. \& Banks, R.G., 2011. Optimizing sheep breeding programs with genomic selection. Proceedings of the Association for the Advancement of Animal Breeding and Genetics 19, 315-321.

Van der Werf, J.H.J., Banks, R.G., Clark, S.A., Lee, S.J., Daetwyler, H.D., Hayes, B.J. \& Swan, A.A., 2014. Genomic Selection in Sheep Breeding Programs. Proceedings of the $10^{\text {th }}$ World Congress on Genetics Applied to Livestock Production. Accessed from https://asas.org/docs/default-source/wcgalpproceedings-oral/351_paper_10381_manuscript_1648_0.pdf?sfvrsn=2 on 15 September 2014.

Van Marle-Köster, E., Neser, F.W.C., Van Wyk, J.B., Visser, C. \& Cloete, S.W.P., 2013a. Genomic selection for the SA livestock industry: Lessons learnt over the past decade. Proceedings of the $46^{\text {th }}$ Congress of the South African Society for Animal Science, 23-26 June 2013, Bloemfontein, South Africa. pp. 1-6.

Van Marle-Köster, E., Visser, C. \& Berry, D.P., 2013b. A review of genomic selection - Implications for the South African beef and dairy cattle industries. S. Afr. J. Anim. Sci. 43, 1-17.

Van Wyk, J.B., Swanepoel, J.W., Cloete, S.W.P., Olivier, J.J. \& Delport, G.J., 2008. Across flock genetic parameter estimation for yearling body weight and fleece traits in the South African Dohne Merino population. S. Afr. J. Anim. Sci. 38, 31-37.

Weigel, K.A., Van Tassell, C.P., O'Connell, J.R., VanRaden, P.M. \& Wiggans, G.R., 2010. Prediction of unobserved single nucleotide polymorphism genotypes of Jersey cattle using reference panels and population-based imputation algorithms. J. Dairy Sci. 93, 2229-2238.

Wiggans, G.R., VanRaden, P.M., Bacheller, L.R., Tooker, M.E., Hutchison, J.L., Cooper, T.A. \& Sonstegard, T.S., 2010. Selection and management of DNA markers for use in genomic evaluations. J. Dairy Sci. $93,2287-2292$. 
Zishiri, O.T., Cloete, S.W.P., Olivier, J.J. \& Cloete, S.W.P., 2010. Genetic trends in South African terminal sire breeds. S. Afr. J. Anim. Sci. 5 (Suppl. 1), 438-441.

Zishiri, O.T., Cloete, S.W.P., Olivier, J.J. \& Dzama, K., 2013a. Genetic parameters for growth, reproduction and fitness traits in the South African Dorper sheep breed. Small Rumin. Res. 112, 39-48.

Zishiri, O.T., Cloete, S.W.P., Olivier, J.J. \& Dzama, K., 2013b. Genetic trends for objectively measured and subjectively assessed traits in a Dorper sheep flock. Trop. Anim. Health Prod. 45, 517-524.

Zishiri, O.T., Cloete, S.W.P., Olivier, J.J. \& Dzama, K., 2014. Genetic parameters for live weight traits in South African terminal sire breeds. Small Rumin. Res. 116, 118-125. 